\title{
Do Bank Size and Liquidity Position Matter in the Monetary Policy Transmission Mechanism? Evidence from Islamic and Conventional Banks in Pakistan
}

\author{
Abdul Rashid ${ }^{1 *}$, Muhammad Abdul Rehman Shah ${ }^{2}$ \\ ${ }^{1}$ Associate Professor/Chairman, Research International Institute of Islamic Economics (IIIE), \\ International Islamic University (IIU), Islamabad, Pakistan \\ ${ }^{2}$ Department of Basic Sciences and Humanities, University of Engineering and Technology (UET), \\ Taxila, Pakistan
}

\author{
Keywords \\ Monetary Policy (MP) \\ Tightening \\ IBs \\ CBs \\ Monetary Transmi- \\ ssion Mechanism \\ Bank Size \\ Bank Liquidity
}

Received: 23-Mar-19

Accepted: 10-Dec-19

\begin{abstract}
An empirical examination of the Tight Monetary Policy (TMP) effects on the financing decisions of banks is of significance for an in-depth understanding of the Credit Channel of Monetary Policy (CCMP). Therefore, this paper aimed at examining the relative role of Islamic and Conventional Banks (CBs) in transmitting the effects of monetary tightening in Pakistan. It also examines whether TMP influences banks' credit expansion differently across bank size and liquidity position. The empirical analysis consists of 11 Islamic Banks (IBs) (5 full-fledged IBs and 6 Islamic branches of CBs) and seventeen CBs with an unbalanced annual bank-level panel dataset covering the period 2005-2016. The results reveal that both types of banks significantly cut their financing in periods of TMP, confirming the existence of the credit channel. The results also indicate that TMP affected IBs less than their conventional peers. The results also provide evidence that large-sized and more-liquid Islamic as well as CBs respond less to the TMP. The findings suggest that the MP authorities may take into consideration the type of banking, bank size, and liquidity position to effectively control credit amounts in the economy.
\end{abstract}

KAUJIE Classification: Q2, L32

JEL Classification: G15; E42; E52; G21

(C) 2019 JIBM. All rights reserved.

\section{INTRODUCTION}

The primary objectives of MP are to enhance economic development and growth and achieving the financial stability of the economic system. Several traditional theories of MP consider Money Supply (MS) as a key device, which is used to attain these objectives. Advocates of these theories argue that any changes in MS would affect interest rates and aggregate spending in an economy (Friedman \& Schwartz, 1963; King \& Plosser, 1984; Sims, 1992).

\footnotetext{
*Corresponding author: Abdul Rashid

†Email: abdulrashid@iiu.edu.pk
} 
In contrast, according to the new MP theories, commercial banks also have essential roles to play in the Monetary Policy Transmission Mechanism (MPTM) (Bernanke, Gertler, \& Gilchris, 1995; Kashyap \& Stein, 1994). Nevertheless, the extent to which banks accelerate the transmission process of MP primarily relies on three characteristics: (1) how much banks are dependent on deposits, (2) how banks' credit expansion is affected by MP shocks; and (3) how much investors and consumers are dependent on bank borrowings.

In principle, there are various channels to transmit the effects of MP in the economy. These channels usually consist of "the asset-pricing channel", "the interest rate channel", "the exchange rate channel", and "the credit channel". Though, "the credit channel of banks" (aka. "bank-centric view of monetary transmission") has vastly been discussed and criticized after recent global financial crisis. This crisis has badly influenced the stability of economic and financial sectors in many developed and developing countries. This channel highlights the role of the banking sector in MPTM. It mainly works through two other channels viz. "the bank lending channel" and "the balance sheet channel" (Bernanke et al., 1995). Keeping in view the failure of "the interest rate channel", Mishkin (1996) is perhaps the first one who formally explained the credit channel of MPTM by exploring the impacts of asymmetric information on capital markets.

Through a comprehensive review of the empirical literature, it is found that several known scholars have confirmed MPTM through both the bank lending and the balance sheet channels for different economies (Bernanke, 1993; Bernanke et al., 1995; Cecchetti, 1999; Hamza \& Saadaoui, 2018; Kashyap \& Stein, 1994). However, these researchers have also reported the effect of MP shocks on banks' lending ability that differs considerably across bank size and banks' liquidity positions.

Similarly, Anwar and Ngyend (2018), Auclert (2017), Aysun and Hepp (2013), Erdogdu (2017), Evans, Fisher, Gourio, and Kran (2015), and Jermann (2019) have found the significance of CBs in MPTM. However, Islamic Financial Institutions (IFIs) have gained popularity in in the last two decades, over the globe. They have attracted the attention of Muslim and Non-Muslim countries. Specifically, Islamic banking industry got popularity during and after the recent global financial/economic crisis of 2007-08. Currently, in several economies, both IBs and CBs are operating parallel to each other. Examples of these countries are Pakistan, Malaysia, Bahrain, UEA, and Turkey. Definitely, in the countries having a dual banking system, any change in MP transmits to the economy through both IBs and CBs. However, compared to CBs, IBs are expected to respond differently to tight MP. We argue this because IBs are relatively quite different with respect to capital structures, asset management, financing arrangements, and composition of equity capital (Nosheen \& Rashid, 2019). The fundamental characteristics of Islamic banking are the prohibition of interest, sharing profits and losses, sharing risks, and assets-backed business transactions (Chaudary \& Mirakhor, 1997). Further, IBs are prohibited to involve in any speculative activities as financial derivatives (Farahani \& Dastan, 2013). Finally, IBs are morally responsible for doing the investments that benefit to general masses and positively contribute to the growth of the real economy. IBs having these exclusive characteristics are highly likely to play a quite different role than the role of their conventional counterparts in MPTM. 
Ibrahim (2017), Kaleem and Isa (2006), Rafay and Farid (2019), and Sukmana and Kassim (2010) and have explored the impacts of MP shocks on IBs' financing decisions. Nevertheless, it should be noted that these studies have utilized aggregated data for analysis. Yet, the bank-level data is used at very limited level. One should also note that the study of Zaheer, Ongena, and Wijnbergen (2013) is an exception, which has used a panel dataset of 40 banks including Islamic banking branches of the CBs from Pakistan. They provided evidence that IBs continue to increase their financing even in periods of tight MP. Further, they found that the MP contraction has greater effects on small-sized banks than their large-sized counterparts ${ }^{1}$.

No doubt, empirical investigation of the response of IBs and CBs to the MP tightening on the basis of bank-level data would be highly significant for understanding MPTM and for selecting effective MP instruments to attain the objectives of the MP in an economy. Given the strong empirical findings on the role of banks in MPTM in the literature and the stylized facts regarding the growth of IBs across the globe (Rashid, Riaz, \& Zaffar, 2017), it would be interesting to examine whether IBs play a different role in MPTM than that of their conventional peers. Knowing this is very important for designing an effective MP in economies with dual banking systems. It will be also useful to study whether bank size and liquidity position matter in formulating banks' responses to TMP.

Many studies have found "the credit channel" in CBs and demonstrated that both bank size and liquidity are important in establishing this channel (Hasin \& Majid, 2012; Janjua, Rashid, \& Qurrat-ul-Ain, 2014; Kashyap \& Stein, 1994; Schmitz, 2004). Nonetheless, no study has hitherto been done to empirically examine these phenomena for IBs. To bridge this vacuum, this paper provides first-hand empirical evidence on the comparative role of IBs and $\mathrm{CBs}$ in transmitting the MP effects. The paper also provides a preliminary examination of the bank size and liquidity stock of IBs and CBs in formulating their reactions to the MP tightening. For this purpose, we have utilized a sample of seventeen CBs and eleven IBs (five full-fledged IBs, and six Islamic branches/divisions of CBs) of Pakistan. The "dynamic panel data (aka. system-GMM) estimator" developed by Arellano and Bover (1995) and Blundell and Bond (1998) has been applied to carry out the empirical analysis. This estimator enables scholars to mitigate the problem of cross-sectional heteroskedasticity and endogeneity.

This study adds to the several aspects of the literature on the MPTM. First, the majority of prior studies have emphasized on CBs while examining the credit channel of MP (Janjua et al., 2014; Kashyap \& Stein, 1994), whereas, we examine this issue for both CBs and IBs. Second, unlike prior studies in Pakistan that do not consider the size and liquidity positions of IBs (e.g., Rafay \& Farid, 2019; Zaheer et al., 2013), we divide both IBs and CBs based on their size and liquidity positions while examining TMP. Third, our research framework allows us to directly compare the impacts of TMP on banks' credit supply across bank types, across bank size, and across liquidity positions of banks.

The rest of the paper is structured as follows. Section 2 presents a review of the empirical literature on MPTM. Section 3 explains the data and presents the empirical framework. Section 4 displays the empirical findings of study. Finally, we present some conclusions and

${ }^{1}$ See Literature Review in the next section for how our study differs from Zaheer et al. (2013). 
recommendations.

\section{REVIEW OF EMPIRICAL LITERATURE}

The choice and effectiveness of different policy instruments critically depend on the way MPTM occurs in the economy. MPTM is a link between changes in monetary instruments (MS and interest rates) and the real and nominal macroeconomic indicators such as output, wages, exchange rates, inflation, prices of commodities, and employment position. Both theorists and empiricists have identified several ways through which MP impacts the economy. Recently, the credit channel has gained attention from the academicians and policymakers, specifically after the 2007-08 financial crisis. This channel mainly works through "the bank-lending and balance sheet channels". The responses of banks' credit supply to MP actions are considered as "the bank-lending channel". Hence, the credit channel is as an expansion of the "interest rate channel" of MPTM. Bernanke and Blinder (1988) are the pioneers who explained the role of banks in MPTM.

Later on, Bernanke and Blinder (1995), Kashyap and Stein (1994, 1995, 2000) and Kishan and Opiela (2000), found the bank-lending channel in the USA. Kashyap and Stein (1994) explored the credit supply behaviour of small-sized and large-sized banks to TMP in the USA. They found that the small-sized banks are affected more through reducing their financing than large-sized banks. Bernanke et al. (1995) extended the New Keynesian Model (NKM) to take into consideration the balance sheet channel of MPTM. Similarly, some studies have explored the same phenomenon for the EU countries (Cecchetti, 1999; Ehrmann \& Smets, 2003; Kashyap \& Stein, 1994; Santis \& Surico, 2013). In the same vein, several other empirical studies including Anwar and Nguyend (2018), Auclert (2017), Bernanke, Lown, and Friedman (1991), Gertler and Gilchrist (1993), Jermann (2019) and Wong (2000) also found significant evidence, favouring the credit channel of MPTM.

By applying different and robust econometric techniques, Alaro and Hakeem (2011), Azali (2003), Cevik and Charap (2015), Hasin and Majid (2012), Ibrahim (2005), and Sanrego and Rusydiana (2013) provided conclusive evidence on the existence of the credit channel in the examined countries. Recently, Ekimova, Kolmakov, and Polyakova (2017), Evans et al. (2015), and Olmo, Azofra, and Sáiz (2018), while exploring the banks' centric view of MPTM, provided evidence that the role of banks is significant and important in MPTM in the economy. Further, Hussain (2014) investigated the relative importance of credit and interest rate channels of MP by applying a vector autoregressive approach for Pakistan. He found that the credit channel was dominant during the period 1991-2000, whereas, the interest rate channel appeared more significant over the period 2001-2012.

Another bank-level study by Janjua et al. (2014) has investigated the existence of credit channel in Pakistan for the period 2006-2012. They used three different measures of MP and considered bank size as a moderator. They found an inverse relationship between MP measures and banks' credit expansion. They augmented their baseline model to observe the impact of MP on small versus large-sized banks and found the former small-sized are affected more during episodes of the tight MP. However, they did not distinguish the banks 
included in the sample as IBs and CBs. They also not took into account the level of liquidity while investigating the impact of MP shocks on the financing decisions of banks.

The emphasis of above-mentioned studies was only on the responses of credit supply of CBs to MP actions. However, some studies have explored the role of Islamic banking in transmission mechanism of MP actions in economies (Hardianto, 2004; Kaleem \& Isa, 2006; Rafay \& Farid, 2019; Sukmana \& Kassim, 2010). The effectiveness of MP, to a great extent, relies on how both IBs and CBs respond to any changes in MP.

The existing empirical works on the significance of IBs in MPTM have mainly examined the effects of MP shocks by using the aggregated data on Islamic financing. The key finding of these studies is that the MP shocks have significant negative impacts on Islamic financing. Recently, Omer (2019) found that the effects of MP shocks on the retail prices of IBs are similar to those for CBs. Moreover, he showed that when extra liquidity of IBs is controlled through different measures, the impact of the policy rate on returns of IBs even becomes more profound. More recently, Akhatova, Zainal, and Ibrahim (2016), Rafay and Farid (2019), Stepanchuk and Tsyrennikov (2015), and Zulkhibri and Sukmana (2017) evaluated the relative validity of the credit channel of IBs and CBs by using various MP measures. Hamza and Saadaoui (2018) have confirmed the transmission of MP through IBs' credit channel.

By reviewing the existing literature on Pakistan, we find that there is only one study by Zaheer et al. (2013), which has empirically investigated the effects of MP shocks on banks' financing decisions using bank-level panel date. The authors using data of IBs and CBs found an important role of banks in transmitting the MP effects in Pakistan. They also found that although the response of IBs differs from small banks, they behave similar to large banks in the economy during episodes of tight MP.

Nonetheless, it should be noted that our paper significantly departs from the study of Zaheer et al. (2013) on several grounds. First, we use an extended sample period of 20052016, whereas, their sample period was 2002-2010 when the share of Islamic financing was relatively low. Second, we divide both IBs and CBs based on bank size and liquidity position, whereas, they divided only CBs. Third, several bank-specific and macroeconomic variables are used as control variables in our specification. Last but not least, we have applied the two-step system GMM estimator, which is very effective in the case of dynamic models and in controlling the problem of cross-section heteroskedasticity and endogeneity.

\section{EMPIRICAL FRAMEWORK, DATA, AND ESTIMATION METHOD}

\section{Empirical Models}

To achieve the first objective of the study, we augment the empirical model estimated by Janjua et al. (2014), and Kashyap and Stein (1994) by including dummies for bank size. Specifically, we interact "small-sized bank dummy" $\left(D_{i t}^{\text {small }}\right)$ and "large-sized bank dummy" $\left(D_{i t}^{\text {large }}\right)$ with the indicators of MP to inspect how TMP affects the credit supply of banks across bank size. The model takes the following form. 


$$
Y_{i t}=\rho_{i}+X_{i t} \alpha+Z_{t} \theta+\beta_{1} K I B O R_{t} \times D_{i t}^{\text {Small }}+\beta_{2} K I B O R_{t} \times D_{i t}^{\text {Large }}+\mu_{t}+\varepsilon_{i t}
$$

where:

$Y_{i t}=$ Banks' credit supply.

$X_{i t}=$ A matrix of banks' factors.

$Z_{t}=$ A matrix containing GDP growth and inflation.

$K I B O R_{t}=$ A MP measure (The Karachi Interbank Offer Rate (KIBOR)).

$D_{i t}^{\text {Small }}=1$, if the log value of Total Assets (TA) of a bank is less in a given year than the mean value of TA of all banks over the sample period, otherwise 0 .

$D_{i t}^{\text {Large }}=1$, if the log value of TA of a bank is greater in the given year than the mean value of TA of all banks over the sample period, otherwise 0 .

$\rho_{i}=$ Individual-specific effects

$\mu_{t}=$ Year-specific effects

$\varepsilon_{i t}=$ Error term

To examine the second objective of the study, we augment the model of (1) by introducing the banking type. In particular, the model is expressed as follows.

$Y_{i t}=\begin{aligned} & \rho_{i}+X_{i t} \alpha+Z_{t} \theta+\beta_{1} K I B O R_{t} \times D_{i t}^{S I B}+\beta_{2} K I B O R_{t} \times D_{i t}^{L I B}+\beta_{3} K I B O R_{t} \times D_{i t}^{S C B}+ \\ & \beta_{4} K I B O R_{t} \times D_{t i}^{L C B}+\mu_{t}+\varepsilon_{i t}\end{aligned}$

In equation (2), $D_{i t}^{S I B}, D_{i t}^{L I B}, D_{i \tau}^{S C B}$ and,$D_{i \tau}^{L C B}$, are the dummies for small IBs, large IBs, small CBs, large CBs, respectively. The other variables are already explained in (1). The estimation of (2) enables us to observe the impact of TPM on the credit supply of IBs and CBs across the size of banks.

We interact liquidity indicators with MP measures to investigate the liquidity position of bank in MPTM, and re-estimate the following model.

$$
Y_{i t}=\rho_{i}+X_{i t} \alpha+Z_{t} \theta+\beta_{1} K I B O R_{t} \times D_{i t}^{L L}+\beta_{2} K I B O R_{t} \times D_{i t}^{M L}+\mu_{t}+\varepsilon_{i}
$$

Finally, we estimate another specification where we consider the liquidity position of IBs versus CBs responding to tight MP. The augmented model takes the following position.

$$
\begin{aligned}
Y_{i t}= & \rho_{i}+X_{i t} \alpha+Z_{t} \theta+\beta_{1} K I B O R_{t} \times D_{i t}^{L L I B}+\beta_{2} K I B O R_{t} \times D_{i t}^{M L I B}+\beta_{3} K I B O R_{t} \\
& \times D_{i t}^{L L C B}+\beta_{4} K I B O R_{t} \times D_{i t}^{M L C B}+\mu_{t}+\varepsilon_{i t}
\end{aligned}
$$

where $D_{i \tau}^{L L I B}, D_{i t}^{M L I B}, D_{i t}^{L L C B}$, and $D_{i t}^{M L C B}$ represent less-liquid and more-liquid IBs, lessliquid and more liquid $\mathrm{CBs}$, respectively.

We include a one-period lagged dependent variable as an explanatory variable in all the above models to control the inertia/persistence in the credit supply decisions of banks. 


\section{Data and Sample}

This paper uses a sample of seventeen conventional and eleven IBs (where five banks are full-fledged IBs and six are the Islamic branches of CBs) and seventeen CBs of Pakistan with an unbalanced annual bank-level panel dataset covering the period 2005-2016. Following the existing literature, the KIBOR is used as a measure of MP. ${ }^{2}$ The data on bank-specific variables are taken from the financial statements of IBs and CBs. Data on MP measures are collected from "Monetary and Financial Statistics" of the "State Bank of Pakistan" (SBP). We also collected some data from "Statistical Publications and Banking Statistics of SBP", and "Orbis Bank Focus (Bankscope)". Some data of banks is got from "Thomson Reuters Datastream". The bank-specific variables are defined in Table 1.

TABLE 1

Description of Bank-Specific Variables

\begin{tabular}{ll}
\hline \hline Names of Variables & Description \\
\hline Bank Credit Supply (CBs) & Gross Loans/Total Assets \\
Bank Credit Supply (IBs) & Gross Financing/Total Assets \\
Bank Size & Ln (Total Assets) \\
Liquidity & Cash \& Equivalents/Total Assets \\
Capital & Total Shareholder Equity/Total Assets \\
Coverage Ratio & EBIT/Interest Expanse \\
Credit Risk & Classified Loans/Total Loans \\
Profitability & Profit after Tax/Total Assets \\
Debt to Equity Ratio & Debt/Equity \\
\hline \hline
\end{tabular}

The banks' credit supply is the dependent variable in the study. Following the existing literature, the ratio of gross loans to total assets is considered the measure of the credit supply of CBs (Kashyap \& Stein, 2000), whereas, the ratio of gross financing to total assets is defined as the IBs' credit supply (Akhatova et al., 2016).

It is notable that there are some discrepancies in heads of the financial statements of CBs versus IBs in the accounting treatment of different activities. Especially, Islamic branches of CBs are dealt in annexures of financial statements with the title of "Islamic Banking Business" as an essential requirement of regulator, the central bank. These annexures consist of all basic heads of the business of Islamic banking enabling the users to select their concerned data for Islamic banking and financial products.

In CBs, there is a title of "Loans or Advances" for credit supply, whereas, credit supply is mentioned with the title of "Islamic financing" in IBs. Further, Islamic financing is decomposed into murābahah, ijārah, mushārakah, mudāarabah, diminishing mushārakah, salam, and istisnn $\bar{a}^{\prime}$ in balance sheet items. Technically, the depositors' accounts are also different in the two banking systems. In CBs, there is a loan contract for current and saving accounts,

\footnotetext{
${ }^{2}$ Several previous studies have also used interbank offered rate as the instrument of MP. These studies, among many others, include Amarasekara (2008), Caporale, Catik, Helmi, Ali, and Tajik, (2016), Gómez-González, Kutan, Ojeda-Joya, and Ortiz (2016), Hanif and Khan (2012), Ibrahim (2017), and Schmitz (2004), Nguyen, $\mathrm{Vu}$, and $\mathrm{Vu}$ (2016), Sun, Gan, and $\mathrm{Hu}(2010)$.
} 
assigning a relationship of lenders and borrowers for depositors and banks, respectively. On the other hand, IBs deal with current accounts generally on loan basis similar to conventional counterparts, but at zero interest rate; whereas, saving and term deposit accounts are titled with "Investment Accounts" in IBs based on the "mudārabah" contract. ${ }^{3}$ In data collection, we found that saving accounts and investment accounts had vehicle contracts of loan and mudārabah for CBs and IBs, respectively.

\section{Estimation Method}

The robust "two-step system-Generalize Method of Moments (GMM) estimator" is applied for estimation to overcome the issue of endogeneity because it is highly likely that the lag value of dependent variable may correlate with the error term. Initially, Arellano and Bover (1995) have proposed this estimator and then Blundell and Bond (1998) have updated it with modern features. The robustness of the results of "the system GMM estimator" critically depends on the validity of the instruments used in the estimation. Therefore, "the J-test of Hansen (1982)" is applied to test the null hypothesis that the instruments are orthogonal to the error term. Further, it is also essential to make sure the estimated residuals from the model are free from the problem of "the second-order serial correlation". Thus, we use "the Arellano and Bond (1991) AR (2)" test to check the presence of serial correlation in the residuals.

\section{EMPIRICAL FINDINGS}

\section{MP and Credit Supply: Controlling for Bank Size and Liquidity}

The estimation results of equations (1) and (3) are given in Table 1. The results of the diagnostic tests given in Panel B of the table provide strong evidence that the instruments used in the estimation are not correlated with the error term and the estimated residuals do not exhibit the second-order serial correlation in all the three estimated models. Thus, our estimation results are reliable.

In Panel A of Table 2, KIBOR is negatively and significantly associated with credit expansion of small and large banks in Pakistan. This finding implies that banks reduce their financing on average responding to TMP, regardless of their size. In other words, TMP has an adverse impact on the credit supply of both types of banks classified on basis of size. It may also imply that the clients reduce banks' financing as it becomes more expensive. However, the estimated values of coefficient suggest that the adverse effect of the increased interest rate on the financing decisions of small-sized banks is higher as compared to large-sized counterparts. This means that during periods of tight MP, small-sized banks reduce their financing more than their large-sized counterparts do.

\footnotetext{
${ }^{3}$ Lately, IBs in Pakistan have also initiated remunerative Current Accounts based on mudārabah (SBP, IB Bulletin Apr-June, 2019), but a little weightage is given to such deposits and only small return is allocated to them that commensurate the benefits/facilities given to such Business account holders.
} 
TABLE 2

MP and Credit Supply: Considering Bank Size and Liquidity

\begin{tabular}{|c|c|c|c|c|}
\hline \multicolumn{5}{|c|}{ Panel A: Estimation Results } \\
\hline \multirow[b]{2}{*}{ Variables } & \multicolumn{2}{|c|}{ Model 1} & \multicolumn{2}{|c|}{ Model 2} \\
\hline & Coefficient & SE & Coefficient & SE \\
\hline Lagged Credit Supply & $0.691 * * *$ & 0.107 & $0.668 * * *$ & 0.121 \\
\hline Bank Size & $0.035 * * *$ & 0.011 & $0.028 * *$ & 0.012 \\
\hline Bank Liquidity & $0.791 * *$ & 0.178 & $0.108 * * *$ & 0.016 \\
\hline Bank Capital & $0.007 * *$ & 0.003 & 0.042 & 0.342 \\
\hline Coverage Ratio & $0.081 *$ & 0.046 & $0.147 * *$ & 0.067 \\
\hline Credit Risk & $-0.683 * * *$ & 0.135 & $-0.977 * * *$ & 0.230 \\
\hline Bank Profitability & $0.020 * * *$ & 0.006 & $0.022 * * *$ & 0.006 \\
\hline Debt to Equity Ratio & 0.005 & 0.011 & $0.010 *$ & 0.005 \\
\hline $\mathrm{KIBOR} \times D^{\text {Small }}$ & $-0.104 * * *$ & 0.016 & & \\
\hline KIBOR $\times D^{\text {Large }}$ & $-0.074 * * *$ & 0.018 & & \\
\hline $\mathrm{KIBOR} \times D^{\text {Less }}$ & & & $-0.007 * * *$ & 0.001 \\
\hline $\mathrm{KIBOR} \times D^{\text {More }}$ & & & $-0.003 * *$ & 0.001 \\
\hline GDP Growth & $0.045 * * *$ & 0.009 & $0.011 *$ & 0.006 \\
\hline Inflation & $0.024 * *$ & 0.011 & $0.024 *$ & 0.013 \\
\hline Constants & $0.811 * * *$ & 0.277 & $0.486^{*}$ & 0.295 \\
\hline \multicolumn{5}{|c|}{ Panel B: Diagnostic Tests } \\
\hline No. of Observations & 194 & 194 & & \\
\hline No. of Banks & 27 & 27 & & \\
\hline No. of Instruments & 39 & 31 & & \\
\hline $\mathrm{AR}(2)$ & 1.49 & 1.56 & & \\
\hline$p$-value & 0.419 & 0.119 & & \\
\hline$J$-statistic & 15.38 & 13.62 & & \\
\hline$p$-value & 0.950 & 0.754 & & \\
\hline
\end{tabular}

Notes: The $J$-statistic is the test for over identified restrictions to ensure the validity of the instruments. Similarly, it is distributed as chi-squared for the null of instrument validity and the Arellano and Bond AR (1991) (2) test is to observe the second-order serial correlation in the residuals. The instruments for both are the two to third lags. $* * * p<0.01, * * p<0.05, * p<0.1$

We observe that small banks reduce their financing by $10.4 \%$, on average, whereas, largesized banks reduces financing by only $7.4 \%$ in response to a one per cent increase in the KIBOR. This finding suggests that when the SBP tightens the MP by rising interest rates, banks face difficulties and cut back their financing. During periods of monetary contractions, banks may have limited financing. This is because the central bank drains reserves out of the banking system, and so, it reduces the monetary base of the banks. As a result, banks become unable to offer more financing and hence, reduce their credit supply. The results indicate that the banks that are small in size are affected more. The empirical evidence on the negative impact of KIBOR on bank credit expansion supports the presence of a "bank-centric view of MPTM" in the banks of Pakistan. The findings suggest that the investors and managers of small-sized banks should be more cautious during episodes of tight MP as small banks are 
affected more by adverse MP shocks. The empirical results given in Table 2 are in favour of the presence of "the bank-centric view of MP" (Kashyab \& Stein, 1994). Likewise, Hasin and Majid (2012), Janjua et al. (2014), Sharpe (1995), and Zaheer et al. (2013) have documented the similar findings.

Looking at the estimated coefficients of bank-specific variables we find that in Model 1 of Table 2, a one-period lag of the depended variable is significantly and positively associated with the credit expansion of banks. It means the banks supplying credit in last year, are willing to supply more credit in current year as well. This finding also provides evidence of the presence of inertia in banks' credit supply. Further, the positive and significant coefficient of the lagged dependent variable not only confirms the dynamic nature of the credit supply model, but also indicates a significant convergence in the long run. However, the estimated magnitude of the coefficient of the lagged credit supply presented in the table suggests that banks adjust their credit supply towards the long-run equilibrium with a speed of about $31 \%$ per year.

Investigating the coefficient of the bank size variable, we observe that credit supply significantly increases with bank size. It implies that larger banks may enjoy the economies of scale through expanding the credit to market. Larger banks are generally financially sound and face less financial distress, and so, offer more financing. In line with same positive association of bank size and credit supply, we find the existing empirical literature (Alper, Hulagu, \& Keles, 2012; Köhler, Hommel, \& Grote, 2006; Schmitz, 2004). In contrast to above finding, Janjua et al. (2014) and Pruteanu-Podpiera (2007) have found the credit supply of CBs is negatively associated with bank size.

The coefficient of bank liquidity is positive and appears statistically significant, suggesting that banks' liquidity is positively linked to the credit supply of banks (Hasin \& Majid, 2012; Schmitz, 2004). One possible explanation of the positive effect of bank liquidity is that banks operating in Pakistan may hold less cash \& equivalent securities in their tills and do aggressively profitable investments in the real sector of the economy. However, some other studies have documented a negative and significant relationship between liquidity and banks' loan supply decisions (Alper et al., 2012; Köhler et al., 2006).

The estimation results also reveal that bank capital and coverage ratio have positive association with banks' credit supply. More specifically, we observe that the coefficient of bank capital is statistically significant with a value of 0.007 , indicating that banks increase their supply of credit with bank capital. This result implies that banks that have better capitalization are expected to issue more credit. Bernanke et al. (1991), Girardin and Moussa (2011), and Schmitz (2004), and have also confirmed this relationship. Further, our finding of positive association of bank capital and credit expansion supports the view of monetarists that banks with better capital position are more likely to bear negative shocks in periods of contractions of MP and may offer more financing.

The coefficient of the coverage ratio is positive and appears statistically significant at the acceptable level of significance in two out of three estimated models, suggesting that banks with higher earnings before taxes relative to rent paid to participants increase their supply of credit. Alaro and Hakeem (2011), and Sanrego and Nikmawati (2010), have also reported 
the similar finding. Nevertheless, this finding is inconsistent with Janjua et al. (2014). They showed a negative and statistically insignificant effect of the coverage ratio on bank credit supply in the case of CBs in Pakistan.

The coefficient of credit risk is negative and has a value of -0.683. It is also statistically significant at an acceptable level. This finding implies that a bank cuts its financing as the credit risk of a bank increases, the bank becomes conscious in issuing new loans, and so, declines its financing. Another possible explanation of such finding is that in periods when banks face more credit risk, they decrease their lending and may prefer to hold excess cash in their hands to get buffer against any insolvency in the future. This finding is consistent with Janjua et al. (2014) and Pruteanu-Podpiera (2007), who have also reported the negative impact on bank credit expansion of the increased credit risk.

The coefficient of the profitability of banks is positive to the dependent variable. Specifically, the estimated value lies in the range of 0.18 to 0.23 (see Tables 2 and 3), indicating that the higher the profitability of the bank the higher the credit supply of the bank. This finding makes sense as more profitable banks have capacity to provide funds to their clients due to having enough internally generated funds.

The capital structure of banks, namely, the debt to equity ratio, is positively but statistically insignificantly bank lending decisions. This finding implies that banks having more debt relative to equity in the composition of the structure of their assets are expected to supply more credit to their customers; but this relationship is statistically weak. This finding is consistent with the finding of Janjua et al. (2014). The last but not the least, the estimated coefficients of the variable GPD growth and the rate of inflation are positive, and both appear statistically significant at any acceptable level of significance. Following the existing literature on bank credit supply we use the growth of GDP as a proxy for demand for loanable funds. Thus, the positive effect of GDP growth on bank credit supply suggests that banks are likely to do more financing during periods when economic growth (demand for loanable funds) is higher. During periods of high economic growth, banks usually feel easy to finance both consumers and business firms. Hence, banks expand their both investment and consumer financing in a growing economy. Further, in periods of good macroeconomic conditions, investment projects may yield relatively higher returns motivating banks to supply more credits. The results also suggest that banks increase their credit supply in episodes of higher inflation. The positive relationship between the rate of inflation and the credit supply decisions of banks may also be rationalized. During periods of higher inflation, since business firms may earn higher profits and since flourishing firms seem willing to have financing on relatively difficult terms and conditions of banks, banks' credit supply increases.

After having provided strong evidence of the existence of the credit channel for both large-sized and small-sized banks, we study the response of banks' credit supply on basis of liquidity. To do so, we estimate the augmented model in equation (3), where we multiply the dummy of a bank's liquidity position (low and high) with the underlying MP indicator. The estimation of this regression model enables us to evaluate the impact of tight MP on the credit supply of less- and more-liquid banks. The results are given in Table 2 under Model 2 heading. Panel B of the table shows the results of the diagnostics tests. The estimated value 
of the j-test and the AR (2) test do not provide any significant evidence of the correlation between the instruments and the error term, and of the presence of the second-order serial correlation in the estimated residuals. Further, the results given in the table indicate that the effects of the lagged depended variable, control variables (whether these are bank-specific or macroeconomic) are generally similar, both in terms of sign and statistical significance, to those presented in Model 1. Therefore, to save space, we do not do commentary on these results. Rather, we focus on the results of the variable of interest: the interaction terms between low- and high-liquidity and MP measures.

The results indicate that the MP measure is significantly and negatively related to the credit supply decisions of both less- and more-liquid banks. However, the results show that banks having a poor liquidity position are likely to be affected more by MP tightening than the banks with a higher level of liquidity. Put differently, although the banks of Pakistan, both low and high liquid, decrease their credit supply in periods of tight MP, low-liquid banks do so more destructively.

Based on empirical results, we find that less-liquid banks decrease their financing by $0.7 \%$ more, whereas, more-liquid banks cut their financing by $0.3 \%$ less in response of a $1 \%$ increase in the KIBOR. These findings suggest that banks' liquidity position plays a vital role in establishing the credit channel of the MP transmission mechanism in Pakistan. These findings suggest that banks having more liquidity may easily adjust the monetary tightening by using their liquid assets as a buffer against any adverse MP shocks and thus, the credit supply of such banks exhibits less sensitivity to the increased interest rate. Another possible explanation for more-liquid banks being less affected by the tight MP is that banks having more liquidity rely less on external sources of financing. Consequently, they may cut less their financing to their customers in episodes of tight MP. On the other hand, banks with a poor liquidity position face financial distress and the cost of this financial distress is likely to be increased during periods of monetary tightening. Thus, they have to cut their financing by a higher amount as a result of the increased market interest rate.

Hasin and Majid (2012), Kashyab and Stein (1994, 1995, 2000), Santis and Surico (2013), Schmitz (2004), and Malede (2014) have also found same empirical evidence for the abovementioned variables. Further, Santis and Surico (2013) have found an excessive cost of capital creates a lot of problems for small-sized, less-liquid, and less-capitalized banks. In this context, less-liquid banks are likely to face difficulties more as compared to more-liquid banks in case of Tight MP. Similarly, Köhler et al. (2006) documented the same credit channel in the Baltic region on the basis of banks' capital and liquidity position of banks. They showed that the banks with poor liquidity and weak capital position appear to be more affected due to the MP actions, whereas, more liquid and more capitalized banks are found to absorb the MP actions.

\section{MP and the Credit Supply of Banks: Controlling for Bank Type, Bank Size, and Bank Liquidity Position}

In the previous subsection, we have presented strong evidence of the influence of MP tightening on the credit supply decisions of banks. We have also reported that the impact of tight 
MP on the credit expansion of small-sized banks and the banks with less liquid assets are higher than their other counterparts. Further, we move to examine whether the banking type, Islamic versus conventional, matters in establishing the impacts of monetary tightening in this subsection. Specifically, to explore the impact of MP tightening on the credit expansion of banks across bank types and bank size, we run the regression models given in equations (2) and (4). The estimation results are given in Table 3. Panel A and Panel B of the table present the estimation results of the bank specific, policy, and the macroeconomic variables and the diagnostic tests, respectively.

The results of the diagnostic tests provide strong evidence of the orthogonality of the instruments and the absence of the second-order serial correlation in the estimated residuals. The results of the control variables (whether these are bank-specific or macroeconomic) are consistent with those given in Table 2. Therefore, to economize on space, we suppress discussion of these results here and emphasize only on the results of the monetary measures. By using indicators, we first divide the full sample of banks into IBs and CBs and then under each category, the banks are further divided into small and large banks as well as less and more liquid banks.

Specifically, we interchange the four generated dummies with the MP instrument. ${ }^{4}$ The estimated values of the coefficient of four interaction terms provide very fascinating information in both estimated models. The coefficient of the monetary measure for small-sized IBs is negative and has a value of -0.020 , whereas, the corresponding value for large-sized IBs is -0.023 . These magnitudes suggest that although all IBs decrease their financing during episodes of tight MP, the tight monetary effects are higher for small-sized IBs. Put differently, compared to large-sized IBs, small-sized IBs decrease their financing by a higher rate when the interest rate increases in the economy. These findings provide strong evidence of the presence of the credit channel of IBs in Pakistan. Further, these findings suggest that the sensitivity of credit supply to the MP tightening is higher for small-sized IBs than that for large-sized IBs.

${ }^{4}$ Two dummies for bank size (small versus large) and two dummies for banking type (Islamic versus conventional) in Model 1. In Model 2, we replace size dummy with liquidity dummy. 
TABLE 3

MP and Credit Supply of IBs and CBs: Bank Size and Liquidity Effects

\begin{tabular}{|c|c|c|c|c|}
\hline \multicolumn{5}{|c|}{ Panel A: Estimation Results } \\
\hline \multirow[b]{2}{*}{ Variables } & \multicolumn{2}{|l|}{ Model 1} & \multicolumn{2}{|l|}{ Model 2} \\
\hline & Coefficient & SE & Coefficient & SE \\
\hline Lagged Credit Supply & $0.428 * * *$ & 0.101 & $0.389 * * *$ & 0.072 \\
\hline Bank Size & $0.077 * * *$ & 0.022 & $0.076 * * *$ & 0.022 \\
\hline Bank Liquidity & $0.732 * *$ & 0.361 & $0.119 * * *$ & 0.040 \\
\hline Bank Capital & $0.004 * *$ & 0.002 & $0.005 * * *$ & 0.001 \\
\hline Coverage Ratio & $0.010^{* *}$ & 0.005 & $0.014 * *$ & 0.006 \\
\hline Credit Risk & $-0.335^{* *}$ & 0.142 & $-0.402 * *$ & 0.158 \\
\hline Bank Profitability & $0.018 * * *$ & 0.003 & $0.023 * * *$ & 0.004 \\
\hline Debt to Equity Ratio & 0.003 & 0.002 & -0.024 & 0.022 \\
\hline $\mathrm{KIBOR} \times D^{S I B}$ & $-0.020 * * *$ & 0.004 & & \\
\hline $\mathrm{KIBOR} \times D^{L I B}$ & $-0.023 * * *$ & 0.008 & & \\
\hline $\mathrm{KIBOR} \times D^{S C B}$ & $-0.036 * * *$ & 0.008 & & \\
\hline $\mathrm{KIBOR} \times D^{L C B}$ & $-0.032 * * *$ & 0.007 & & \\
\hline $\mathrm{KIBOR} \times D^{L L I B}$ & & & $-0.019 * * *$ & 0.006 \\
\hline KIBOR $\times D^{M L I B}$ & & & $-0.016 * * *$ & 0.005 \\
\hline $\mathrm{KIBOR} \times D^{L L C B}$ & & & $-0.033 * * *$ & 0.008 \\
\hline $\mathrm{KIBOR} \times D^{M L C B}$ & & & $-0.029 * * *$ & 0.008 \\
\hline GDP Growth & $0.175 * * *$ & 0.067 & $0.210 * * *$ & 0.033 \\
\hline Inflation & 0.016 & 0.016 & 0.017 & 0.012 \\
\hline Constants & $0.588 * * *$ & 0.229 & $0.706^{* * *}$ & 0.115 \\
\hline \multicolumn{5}{|c|}{ Panel B: Diagnostic Tests } \\
\hline No. of Observations & & 248 & & 248 \\
\hline No. of Banks & & 27 & & 27 \\
\hline No. of Instruments & & 31 & & 30 \\
\hline $\mathrm{AR}(2)$ & & 0.54 & & 0.20 \\
\hline$p$-value & & 0.592 & & 0.843 \\
\hline$J$ - statistic & & 9.27 & & 12.60 \\
\hline$p$-value & & 0.902 & & 0.633 \\
\hline
\end{tabular}

Turning to the results for CBs, we find that the estimated values of the coefficient of monetary measures are negative and significant for both size categories. However, we observe that similar to the case of IBs, small-sized CBs are affected more due to TMP than large-sized CBs. The coefficient of the monetary measure for small-sized CBs is -0.036 , whereas, the corresponding value for large-sized CBs is -0.032 . These coefficients suggest the presence of "bank-centric view" of MPTM for CBs. These findings also suggest that the impacts of TMP on the credit expansion of CBs differ across banks' size. In other words, the results reveal that during periods of MP tightening, although both categories of CBs reduce their credit supply, small-sized CBs decline their credit supply by a higher amount. 
By doing a comparison of the response of IBs and CBs to the tightening of MP we observe several noticeable aspects. The estimated magnitudes of the coefficient of the monetary measure indicate that the sensitivity of the credit supply of small- and large-sized IBs to the MP tightening is lower than that of their small- and large-sized conventional counterpart banks, respectively. Specifically, we find that compared to small CBs, small IBs are affected less adversely by the tight MP. For instance, when the interbank offered rate increases by $1 \%$, small IBs decrease their financing by $1.9 \%$, whereas, small CBs decrease their credit supply by $3.6 \%$.

Similarly, the results show that compared to large-sized CBs, large-sized IBs cut back the financing by a smaller amount in periods of tight MP. Specifically, based on the estimated size of the coefficient, large CBs decrease their credit supply by $3.2 \%$, whereas, large-sized IBs reduce their financing by $2.3 \%$ in response to a $1 \%$ increase in the KIBOR. These findings provide strong evidence on the different sensitivity of credit supply of IBs and CBs to MP. It is also evident from the results given in Table 3 that the effectiveness of the credit channel of the MP transmission mechanism considerably depends on both the nature of the banking (Islamic and conventional) and the size categories of banks (small and large). Finally, the results in the table suggest that there are substantial variations of the MP tightening on credit supply decisions of banks across small and large size categories, both within IBs and CBs and as between IBs and CBs.

After having found the different response of banks on basis of liquidity to the MP tightening (see Model 2 of Table 2), we provide another set of results in Table 3 in column with heading Model 2 to evaluate whether the role of banks' liquidity position remains robust in creating the credit channel at both IBs and CBs. We estimate equation (4) where we consider the types of banks (Islamic and conventional) over and above the banks' liquidity position (less and more liquid). Similar to our other estimations, based on the estimated statistics of the diagnostic tests, we conclude that our instruments are orthogonal to the error term and the residuals do not demonstrate any pattern of serial correlation.

The results of the lagged dependent variable, control variables (whether these are bankspecific or macroeconomic) are quite similar to our early findings on these variables given in the previous table. Specifically, we find that the lagged value of credit supply is positively and significantly related to the current credit supply, indicating the presence of strong persistence in the credit supply decisions of banks in Pakistan. We also find that bank size, bank capital, bank profitability, the coverage ratio, bank liquidity, and the debt-equity ratio all are positively and significantly related, whereas, credit risk is negatively and significantly related to the credit supply decisions of banks. Likewise, the results regarding the macroeconomic variables show that GDP growth and inflation are positively related to bank lending. Yet, the estimated coefficient of inflation appears statistically insignificant.

By using categorical variables, we first classify the full sample of banks into IBs and $\mathrm{CBs}$ and then under each type, we further split the banks into less- and more-liquid banks based on their liquidity position. Specifically, we interchange the four-constructed dummies (two for IBs and two for CBs) with the MP instrument. The results of the interaction terms provide useful evidence. The coefficient of the monetary measure for less-liquid IBs is -0.019 , 
whereas, the corresponding value for more-liquid IBs is -0.016. All of these estimated values are significant at an acceptable level of significance. Thus, they provide strong evidence that though all IBs are likely to cut their financing during monetary contractions periods, the effects of tight MP are considerably higher for those IBs that have less liquid assets, on average. Said differently, compared to more-liquid IBs, the financing of less-liquid IBs declines by a higher amount when the monetary authorities increase interest rate in the economy. These findings provide strong evidence of the presence of the credit channel of IBs in Pakistan, regardless of their liquidity position. Yet, these findings also demonstrate that the sensitivity of credit supply to the MP tightening is higher for less-liquid IBs in comparison to more-liquid IBs.

Looking at the estimated values of the interaction terms for $\mathrm{CBs}$, we observe that the estimates of the coefficient of the monetary measure are negative and statistically significant for both liquidity categories. However, we find that similar to the case of IBs, less-liquid CBs are being affected more by the tight MP as compared to more-liquid CBs. Specifically, the results indicate that the coefficient of MP measure for less-liquid CBs is -0.033 , whereas, the corresponding value for more-liquid CBs is -0.029 . These coefficients indicate the presence of credit channel for $\mathrm{CBs}$, regardless of their liquidity position. Further, these findings also reflect that the impact of tight MP on the credit expansion of CBs differ across lessand more-liquid banks. In other words, the results reveal that during periods of monetary constrictions, although both categories of CBs reduce their credit supply, less-liquid CBs do so by higher amount.

Comparing the sensitivity of the credit supply decisions of both IBs and CBs to monetary contractions across their liquidity position, we observe several manifest aspects. Both liquidity categories of IBs respond less to monetary contractions than their less- and moreliquid conventional counterparts. Specifically, the results demonstrate that compared to less-liquid CBs, less-liquid IBs are affected less adversely by the tight MP. For instance, when the interbank offered rate increases by $1 \%$, less-liquid IBs decrease their financing by $1.9 \%$, whereas, less-liquid CBs decrease their credit supply by $3.3 \%$ of total assets. Similarly, the estimation results show that compared to more-liquid CBs, more-liquid IBs cut back the financing by a smaller amount in periods of tight MP. Specifically, taking the estimated coefficients at their face value, we find that more-liquid CBs decrease their credit supply by $2.9 \%$, whereas, more-liquid IBs reduce their financing by only $1.6 \%$ of total assets in response to a $1 \%$ increase in the KIBOR in the economy.

These findings provide strong evidence on the different sensitivity of the credit supply of IBs and CBs even after controlling for their liquidity position. It is also evident from the results given in Table 3 that the effectiveness of the credit channel of the MP transmission mechanism considerably depends on both the nature of the banking (Islamic and conventional) and the liquidity position of banks (low and high). Finally, our findings strongly demonstrate that there are considerable disparities in the effects of monetary contractions on financing decisions of banks across liquidity positions, both within IBs and CBs and as between IBs and CBs. Specifically, we observe that more liquid banks (whether they are IBs or CBs) are affected less due to an increase in the interest rate. 
A possible explanation for such findings is that there are fundamental differences in the features of the Islamic banking and conventional banking systems. Moreover, Islamic finance is based upon the variety of contracts that lead to risk-sharing and participatory arrangements, whereas, CBs play the role of financial intermediation through mainly the contracts, which are based upon loans and transfer of risk to clients. These features enable Islamic financial institutions to manage their depository investment accounts on the mudārabah arrangement, where credit risk doesn't transfer from depositors to IBs (Sukmana \& Kasim, 2010).

This finding also suggests that although the structure of IBs is quite different from that of CBs, any monetary tightening by the SPB in terms of increasing interest rate would have an adverse impact on the credit supply decisions of IBs. One of the possible explanations for such finding is that in spite of IBs doing interest-free and Shari'ah compliant financings/investments, they share the same interbank mark and work under the same laws and regulations governing their conventional counterparts. Thus, it is expected that increased interest rates negatively affect IBs' credit supply. The presence of the bank-centric view in the case of IBs suggests that while devising MP instruments to achieve the macroeconomic objective of MP, the authorities should also take into account IBs along with CBs. Finally, the finding of the negative effects of tight MP on IBs' credit supply is consistent with several prior studies in the literature that have documented the same effect for CBs (Hasin \& Majid, 2012; Kashyab \& Stein, 1994; Sharpe, 1995).

In sum, the results of the paper reveal that the monetary tightening has a significant influence on the credit supply decisions of both IBs and CBs. These findings imply that the credit channel of the MP transmission mechanism exists at both IBs and CBs. However, it is relatively less effective in the case of IBs. The findings also suggest that the size of a bank and its liquidity position both have an essential role to play for the effectiveness of the credit channel. Finally, we show that the effects of tight MP on banks' financing decisions are robust to the inclusion of several control variables (whether these are bank-specific or macroeconomic) in the specification.

\section{CONCLUSION}

Both the researchers and the policymakers have considered "the bank credit channel" of MP. In fact, we have a vast body of literature on the impacts of MP on CBs through "the credit channel". Yet, we know less about the behaviour of IBs during periods of monetary tightening. In this paper, we first examine the existence of "the bank-centric view" of MPTM by quantifying the effects of KIBOR on the credit expansion of banks in Pakistan after taking into account their size based on total assets and their liquid positions based on their holdings of cash and equivalent assets. After having found the strong empirical evidence in favour of the credit channel of MPTM in both size and liquidity categories, we further control for the nature of banking, Islamic and conventional. An unbalanced panel dataset of IBs and CBs of Pakistan is used for the period 2005-2016. The "two-step system-GMM estimator" is applied. Finally, our research framework helps us to observe directly the sensitivity of banks' credit supply decisions to monetary contractions across the nature of banking (Islamic versus conventional) and across different categories of banks based on bank size and bank liquidity 
positions.

The results of the paper are recapped as follows. First, we find strong evidence on the presence of "the credit channel" in Pakistani banks by showing that monetary contractions have significant, negative effects on the financing decisions of banks regardless of their size and liquidity positions. Nevertheless, we show that both the size and the liquidity position of banks are very important in establishing the sensitivity of credit supply to the MP tightening. Second, although both IBs and CBs reduce their financing in periods of monetary contractions, the response of IBs is weaker than that of their conventional peers. Third, we find that large-sized and more-liquid IBs as well as CBs react less to the MP tightening as compared to their small-sized and less-liquid IBs and conventional counterparts, respectively. Taken together, the results of the paper provide significant evidence showing that there are considerable differences in the influence of the MP tightening on banks' credit supply decisions in Pakistan across bank size and liquidity positions, both within as well as between IBs and CBs.

\section{Policy Implications}

Several policy implications are emerging from the results of this paper for both MP authorities and the bank managers. First, the central bank of Pakistan can use the interbank offered rates as a policy instrument to effectively control credit amounts as we find the presence of "the credit channel" of the MPTM. Since, during periods of monetary contractions, the financing of banks is affected negatively, banks should smooth their earnings and anchor themself to financial solvency by investing more in real economic activities and depending more on internally generated funds, rather than deposits and external borrowings.

Second, we suggest the policymakers that for an effective MP, they must keep in mind the unique nature and contractual differences of IBs while formulating the instruments of MP, as we show IBs are affected less during episodes of monetary tightening. Otherwise, there may appear puzzles to MP actions and it may become ineffective to efficiently achieve macroeconomic objectives of the policy. Third, we caution that the passive response of IBs, large, and more liquid banks to tight MP in Pakistan may appear as an obstacle for the SBP in attaining the desired goals of MP.

Fourth, the policymakers should consider the size and liquidity position of banks while formulating any policy regarding the market interest rate because we show that TPM has more effects on the credit supply decisions of small and less-liquid banks than their counterparts. This unavailability of suitable MP instruments may lead to a higher intermediation cost and result in higher and persistent inflation. Further, based on the strong evidence of the presence of IBs' credit channel in Pakistan, the policymakers are recommended to consider IBs as a complement channel to MPTM. The results of the paper on MPTM may be generalized to other countries having a dual banking system and similar economic and financial markets structures.

Last but not least, the findings we present here should be an eye-opening experience to the adherents of Islamic finance and banking. This is because they unveil the fact that despite having different structure in principle, IBs' financing is highly adversely influenced owing to the increased market interest rate in the economy. This piece of evidence indicates 
that, rather than doing socially responsible and sustainable investment on economic-based rates of return, IBs largely rely on fixed rate-based investing, which is highly affected by any adjustment in the market interest rate by the central bank. Further, they may often use KIBOR rates as a benchmark for determining their profits and thus, any change in market rates negatively impacts the financing of IBs. For instance, the pricing in the products like running mushärakah, salam, muräbahah to purchase orderer, and ijärah are highly based on KIBOR in Pakistan (Ghauri, 2015; Siddiqi, 2006; State Bank of Pakistan, 2009; Shaikh, 2013; Siddique, 2017). One of the possible alternatives of avoiding the KIBOR consideration is that the benchmark rate for each offering should be based on productivity and economic growth rate, the nature of the underlying offering, the associated risks on the one side, and on the other, the benchmark rate should be in line with Sharī'ah principles.

\section{Future Research Agenda}

This paper provided strong evidence on the presence of "the credit channel" of MP by examining the effects of KIBOR on IBs' and CBs' financing decisions. The research can be further extended by using other types of interest rates such as lending rates, the deposit rate, the spread between bond yields, etc. The paper considered the role of the size and liquidity position of banks in formulating the impact of MP on the credit expansion decisions of banks. However, one can examine the different effects of TMP by considering other bank-specific characteristics such as bank profitability, bank capital, credit risk, etc. It would be also worth exploring the MP effects on banks' deposits, total assets, and their financial health. Finally, from both bank managers' and policymakers' viewpoint, examination of spillover effects of the MP of foreign countries such as the USA and the UK on domestic IBs' and CBs' financing decisions would be worthwhile.

\section{REFERENCES}

Akhatova, M., Zainal, M. P., \& Ibrahim, M. H. (2016). Banking models and monetary transmission mechanisms in Malaysia: Are Islamic banks different? Economic Papers: A Journal of Applied Economics and Policy, 35(2), 169-183.

doi: https://doi.org/10.1111/1759-3441.12131

Alaro, A. R., \& Hakeem, M. (2011). Financial engineering and financial stability: The role of Islamic financial system. Journal of Islamic Economics, Banking and Finance, 7(1), 34-55.

Alper, K., Hulagu, T., \& Keles, G. (2012). An empirical study on liquidity and bank lending (Working paper no. 4). Ankara, Turkey: Central Bank of the Republic of Turkey.

Amarasekara, C. (2008). The impact of monetary policy on economic growth and inflation in Sri Lanka. Staff Studies, 38(1), 1-44. doi: https://doi.org/10.4038/ss.v35i1.1232

Anwar, S., \& Nguyend, L. P. (2018). Channels of monetary policy transmission in Vietnam. Journal of Policy Modelling, 40(4), 709-729. doi: https://doi.org/10.1016/j.jpolmod.2018.02.004

Arellano M., \& Bond S. (1991). Some tests of specification for panel data: Monte Carlo evidence and an application to employment equations. Review of Economic Studies, 
58(3), 277-297. doi: https://doi.org/10.2307/2297968

Arellano M., \& Bover O. (1995). Another look at the instrumental variable estimation of error-components models. Journal of Econometrics, 68(1), 29-51.

doi: https://doi.org/10.1016/0304-4076(94)01642-D

Auclert, A. (2017). Monetary policy and the redistribution channel (NBER working paper 23451). Cambridge, MA: National Bureau of Economic Research.

doi: https://doi.org/10.3386/w23451

Aysun, U., \& Hepp, R. (2013). Identifying the balance sheet and the lending channels of monetary transmission: A loan-level analysis. Journal of Banking E Finance, 37(2), 2812-2822. doi: https://doi.org/10.1016/j.jbankfin.2013.04.006

Azali, M. (2003). Transmission mechanism in a developing economy: Does money or credit matter? Serdang, Malaysia: University Putra Malaysia Press.

Bernanke, B. S. (1993). Credit in the Macroeconomy. Quarterly Review-Federal Reserve Bank of New York, 18, 50-50.

Bernanke, B. S., Lown, C. S., \& Friedman, B. M. (1991). The credit crunch. Brookings Papers on Economic Activity, 22(2), 205-248. doi: https://doi.org/10.2307/2534592

Bernanke, B. S., \& Blinder A.S. (1995). Inside the black box: The credit channel of monetary policy transmission. Journal of Economic Perspectives, 9(4), 27-48. doi: https://doi.org/10.1257/jep.9.4.27

Bernanke, B.S., Gertler, M., \& Gilchrist, S. (1995). The financial accelerator in a quantitative business cycle framework (NBER working paper no. 6455). Amsterdam, Netherlands: National Bureau of Economic Research.

Blundell R., \& Bond, S. (1998). Initial conditions and moment restrictions in dynamic panel data models. Journal of Econometrics, 87(2), 115-143.

doi: https://doi.org/10.1016/S0304-4076(98)00009-8

Caporale, G. M., Catik, A. N., Helmi, M., Ali, F. M., \& Tajik, M. (2016). The bank lending channel in a dual banking system: Evidence from Malaysia (DIW Berlin discussion paper no. 1557). Berlin, Germany: German Institute for Economic Research. doi: https://doi.org/10.2139/ssrn.2745234

Cecchetti, S., G. (1999). Legal structure, financial structure, and the monetary policy transmission mechanism (NBER working paper no. w7151). New York, NY: National Bureau of Economic Research. doi: https://doi.org/10.3386/w7151

Cevik, S., \& Charap, J. (2015). The behavior of conventional and Islamic bank deposit returns in Malaysia and Turkey. International Journal of Economics and Financial, 5(1), 111-124.

Chaudary N, N., \& Mirakhor, A. (1997). Indirect instruments of monetary controlling an Islamic financial system. Islamic Economic Studies, 4(2), 27-65.

Ehrmann, M., \& Smets, F. (2003). Uncertain potential output: implications for monetary policy. Journal of Economic Dynamics and Control, 27(9), 1611-1638.

doi: https://doi.org/10.1016/S0165-1889(02)00073-8

Ekimova, K., Kolmakov, V., \& Polyakova, A. (2017). The credit channel of monetary policy transmission: Issues of quantitative measurement. Economic Annals-XXI, 166, 51-55. doi: https://doi.org/10.21003/ea.V166-10 
Erdogdu, A. (2017). Functioning and effectiveness of monetary transmission mechanisms: Turkey applications. Journal of Finance and Bank Management, 5(1), 29-41. doi: https://doi.org/10.15640/jfbm.v5n1a3

Evans, C., Fisher, J., Gourio, F., \& Kran, S. (2015). Risk management for monetary policy near the zero lower bound. Brookings Papers on Economic Activity, 2015(1), 141-219. doi: https://doi.org/10.1353/eca.2016.0003

Farahani, Y, G., \& Dastan, M. (2013). Analysis of Islamic banks' financing and economic growth: A panel co-integration approach. International Journal of Islamic and Middle Eastern Finance and Management, 6(2), 156-172. doi: https://doi.org/10.1108/17538391311329842

Friedman, M., \& Schwartz, A. J. (1963). A Monetary History of the United States, 18671960. Princeton, NJ: Princeton University Press.

Gertler, M., \& Gilchrist, S. (1993). The role of credit market imperfections in the monetary transmission mechanism: Arguments and evidence. The Scandinavian Journal of Economics, 95(1), 43-64. doi: https://doi.org/10.2307/3440134

Ghauri, S. M. K. (2015). Why interest-rate cannot benchmark for Islamic financial product pricing? Benchmarking: An International Journal, 22(7), 1417-1428.

doi: https://doi.org/10.1108/BIJ-04-2013-0049

Girardin, E., \& Moussa, Z. (2011). Quantitative easing works: Lessons from the unique experience in Japan 2001-2006. Journal of International Financial Markets, Institutions and Money, 21(2), 461-495. doi: https://doi.org/10.1016/j.intfin.2011.01.004

Gómez-González, J. E., Kutan, A. M., Ojeda-Joya, J. N., \& Ortiz, M. C. (2016). The bank lending channel of monetary policy: Does the financial structure of banks matter. Retrieved from https://bit.ly/38smamI

Hamza, H., \& Saadaoui, Z. (2018). Monetary transmission through the debt financing channel of Islamic banks: Does PSIA play a role? Research in International Business and Finance, 45(3), 557-570. doi: https://doi.org/10.1016/j.ribaf.2017.09.004

Hanif, M. N., \& Khan, M. (2012). Pass-through of SBP policy rate to market interest rates: An empirical investigation. Journal of Independent Studies and Research, 10(1), 97-112. doi: https://doi.org/10.31384/jisrmsse/2012.10.1.7

Hardianto, E. (2004). Sharī'ah transmission mechanism in Indonesia. Journal of Economic Cooperation and Development, 8(2), 20-38.

Hasin, Z., \& Majid, M. S. (2012). Islamic banks and monetary transmission mechanism in Malaysia. Journal of Economic Cooperation and Development, 35(2), 137-166.

Hansen, L. P. (1982). Large sample properties of generalized method of moments estimators. Econometrica, 50(4), 1029-1054 doi: https://doi.org/10.2307/1912775

Hussain, S. I. (2014). Monetary transmission mechanism in Pakistan: Credit channel or interest rate channel. Management and Social Sciences E Economics, 12(2), 1-19. doi: https://doi.org/10.31384/jisrmsse/2014.12.2.4

Ibrahim, M. H. (2005). Sectoral effects of monetary policy: Evidence from Malaysia. Asian Economic Journal, 19(1), 83-102. doi: https://doi.org/10.1111/j.1467-8381.2005.00205.x 
Ibrahim, M. H. (2017). The bank lending channel of monetary policy transmission in a dual banking system. Journal of Islamic Monetary Economics and Finance, 2(2), 193-220. doi: https://doi.org/10.21098/jimf.v2i2.656

Janjua, P. Z., Rashid, A., \& Qurrat-ul-Ain. (2014). Impact of monetary policy on bank balance sheet in Pakistan. International Journal of Economics and Finance, 6(11), 187-196. doi: https://doi.org/10.5539/ijef.v6n11p187

Jermann, U. (2019). Negative swap spreads and limited arbitrage (No. w25422). Cambridge, MA: National Bureau of Economic Research. doi: https://doi.org/10.3386/w25422

Kaleem, A., \& Isa, M. (2006). Islamic banking and money demand function in Malaysia: An econometric analysis. Pakistan Economic and Social Review, XLIV(2), 277-290.

Kashyap, A. K., \& Stein, J. C. (1994). Monetary policy and bank lending in monetary policy. National Bureau of Economic Research Studies in Business Cycles, 12(2), 221-262. doi: https://doi.org/10.3386/w4317

Kashyap, A. K., \& Stein, J. C. (1995). The impact of monetary policy on bank balance sheets. Carnegie-Rochester Conference Series on Public Policy, 42(1), 151-195. doi: https://doi.org/10.1016/0167-2231(95)00032-U

Kashyap, A. K., \& Stein, J. C. (2000). What do a million observations on banks say about the transmission of monetary policy? American Economic Review, 90(3), 407-428. doi: https://doi.org/10.1257/aer.90.3.407

King, R. G., \& Plosser, C. I. (1984). Money, credit, and prices in a real business cycle. The American Economic Review, 74(3), 363-380.

Kishan, R. P., \& Opiela, T. P. (2000). Bank size, bank capital, and the bank lending channel. Journal of Money, Credit and Banking, 32(1), 121-141. doi: https://doi.org/10.2307/2601095

Köhler, M., Hommel, J., \& Grote, M. (2006). The role of banks in the transmission of monetary policy in the Baltics (No. w06-005). Mannheim, Germany: Centre for European Economic Research.

Mishkin, F. S. (1996). The channels of monetary transmission: Lessons for monetary policy (No. w5464). Cambridge, MA: National Bureau of Economic Research. doi: https://doi.org/10.3386/w5464

Nguyen, T. N., Vu, H. Y., \& Vu, N. H. (2016). Impacts of monetary policy on asset markets: The case of Vietnam. Review of Business and Economics Studies, 4(3), 39-52.

Nosheen, \& Rashid, A. (2019). Business orientation, efficiency, and credit quality across business cycle: Islamic versus conventional banking. Are there any lessons for Europe and Baltic states? Baltic Journal of Economics, 19(1), 105-135. doi: https://doi.org/10.1080/1406099X.2018.1560947

Olmo, B. T., Azofra, S. S., \& Sáiz, M. C. (2018). Creditor rights and the bank lending channel of monetary policy. In Corporate governance in banking and investor protection (pp. 107-122). Cham, Switzerland: Springer. doi: https://doi.org/10.1007/978-3-319-70007-6_6

Omer, O. (2019). Monetary policy pass-through, excess liquidity and price spillover: A comparative study of conventional and Islamic banks of Pakistan. Journal of Islamic 
Monetary Economics and Finance, 5(2), 287-320.

doi: https://doi.org/10.21098/jimf.v5i2.1064

Pruteanu-Podpiera, A. M. (2007). The role of banks in the Czech monetary policy transmission mechanism. Economics of Transition, 15(2), 393-428.

doi: https://doi.org/10.1111/j.1468-0351.2007.00281.x

Rafay, A., \& Farid, S., (2019). Islamic banking system: A credit channel of monetary policy: Evidence from an emerging economy. Economic Research-Ekonomska Istraživanja, 32(1), 742-754. doi: https://doi.org/10.1080/1331677X.2019.1579662

Rashid, A., Riaz, M., \& Zaffar, A. (2017). Are Islamic banks really different from conventional banks? An investigation using classification techniques. Journal of Islamic Business and Management, 8(1), 37-52.

doi: https://doi.org/10.26501/jibm/2018.0801-003

Sanrego, Y. D., \& Nikmawati, K. (2010). Transmission mechanism of Sharī'ah financing in Malaysia. The Journal of Muamalat $\mathcal{E}$ Islamic Finance Research, 7(1). 121-135.

Sanrego, Y. D., \& Rusydiana A. S. (2013). Transmission mechanism in dual monetary system: Comparison between Sharī'ah and conventional monetary system. Journal of Islamic Economics, Banking and Finance, 9(2). 111-124.

doi: https://doi.org/10.12816/0001600

Santis, R. A., \& Surico, P. (2013). Bank lending and monetary transmission in the Euro area. Economic Policy, 28(75), 423-457. doi: https://doi.org/10.1111/1468-0327.12013

State Bank of Pakistan. (2009). Handbook of Islamic banking products $\mathcal{E}$ services. Karachi, Pakistan: Islamic Banking Department, State Bank of Pakistan.

Schmitz, B. (2004). What role do banks play in monetary policy transmission in EU accession countries. Retrieved from https://bit.ly/37tvsxp

Shaikh, S. A. (2013). Islamic banking in Pakistan: A critical analysis. Journal of Islamic Economics, Banking and Finance, 113(913), 1-18. doi: https://doi.org/10.12816/0001601

Sharpe, S. A. (1995). Bank capitalization, regulation, and the credit crunch: A critical review of the research findings. Finance and Economics Discussion Series, 12(1), 95-20.

Siddiqi, M. N. (2006). Islamic banking and finance in theory and practice: A survey of state of the art. Islamic Economic Studies, 13(2), 1-48.

Siddique, M. A. (2017). Practice of running Mushārakah in Pakistani Islamic banks: An analytical study in the light of Shar'`ah principles. Fikr-O-Nazar, 54(4), 53-110.

Sims, C., (1992). Interpreting the macroeconomic time series facts: The effects of monetary policy. European Economic Review, 36(5), 975-1000.

doi: https://doi.org/10.1016/0014-2921(92)90041-T

Stepanchuk, S., \& Tsyrennikov, V. (2015). Portfolio and welfare consequences of debt market dominance. Journal of Monetary Economics, 74(2), 89-101. doi: https://doi.org/10.1016/j.jmoneco.2015.06.005

Sukmana, R., \& Kassim, S. H. (2010). Roles of the Islamic banks in the monetary transmission in Malaysia. International Journal of Islamic and Middle Eastern Finance and Management, 3(1), 7-19. doi: https://doi.org/10.1108/17538391011033834 
Sun, S., Gan, C., \& Hu, B. (2010). Bank lending channel in China's monetary policy transmission mechanism: A VECM approach. Investment Management and Financial Innovations, 7(2), 59-71.

Wong, K. (2000). Variability in the effects of monetary policy on economic activity. Journal of Money, Credit and Banking, 32(2), 179-198. doi: https://doi.org/10.2307/2601238

Zaheer, S., Ongena, S., \& Van Wijnbergen, S. (2013). The transmission of monetary policy through conventional and Islamic banks (Discussion paper no. 2011-018). Tilburg, Netherlands: European Banking Center, Tilburg University. doi: https://doi.org/10.2139/ssrn.1888345

Zulkhibri, M., \& Sukmana, R. (2017). Financing channels and monetary policy in a dual banking system: Evidence from Islamic banks in Indonesia. Economic Notes: Review of Banking, Finance and Monetary Economics, 46(1), 117-143.

doi: https://doi.org/10.1111/ecno.12076

$* * * * * * * * * * * * * * * *$ 